慶應義塾大学学術情報リポジトリ

Keio Associated Repository of Academic resouces

\begin{tabular}{|c|l|}
\hline Title & Predictors of Vessel Remodeling Following Directional Coronary Atherectomy \\
\hline Sub Title & 冠動脈方向性アテローム切除術後の血管リモデリングの予測因子 \\
\hline Author & 河村, 朗夫(Kawamura, Akio) \\
\hline Publisher & 慶應医学会 \\
\hline Publication year & 2007 \\
\hline Jtitle & 慶應医学 (Journal of the Keio Medical Society). Vol.84, No.2 (2007. 6),p.52- \\
\hline JaLC DOI & \\
\hline Abstract & \\
\hline Notes & 号外 \\
\hline Genre & Journal Article \\
\hline URL & $\begin{array}{l}\text { https://koara.lib.keio.ac.jp/xoonips/modules/xoonips/detail.php?koara_id=AN00069296-2007060 } \\
\text { 2-0052 }\end{array}$ \\
\hline
\end{tabular}

慶應義塾大学学術情報リポジトリ(KOARA)に掲載されているコンテンツの著作権は、それぞれの著作者、学会または出版社/発行者に帰属し、その権利は著作権法によって 保護されています。引用にあたっては、著作権法を遵守してご利用ください。

The copyrights of content available on the KeiO Associated Repository of Academic resources (KOARA) belong to the respective authors, academic societies, or publishers/issuers, and these rights are protected by the Japanese Copyright Act. When quoting the content, please follow the Japanese copyright act. 


\section{Predictors of Vessel Remodeling Following Directional Coronary Atherectomy}

(冠動脈方向性アテローム切除術後の血管リモデリングの予測因子)

\section{河 村 朗 夫}

\section{内容の要旨}

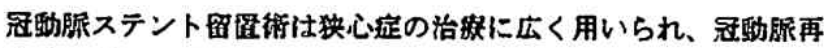

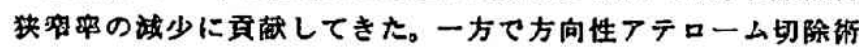

(Directional Coronary Atherectomy : DCA) は㟈䄱脈内アテロームを 切除することが可能な唯一の治旗法である。血铰内超音波法による

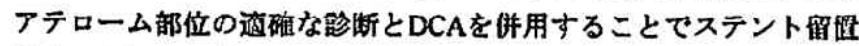
術よりも受れた結果が得られる可能性が示されている。

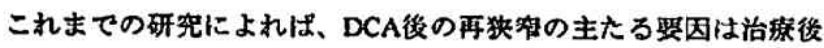
から侵性期にかけて血管が䅂小する現象、すなわち負のリモデリン グであることが指摘されている。アテロームが筀加しても血管径が

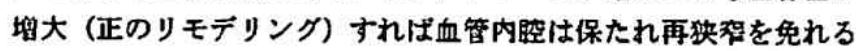

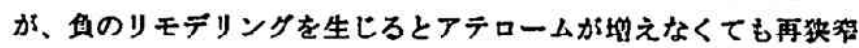
を生しる。これまで、DCA施行後に冠劤脤が正のリモデリングを生 じるのかあるいは俱のリモデリングを生じるかを予測すること は困败であった。本研究では血管内超咅波法を用いてDCA施行後の 冠動脈リモテリングに関与する因子を明らかにすることを目的とし た。

安定狭心定に対しDCAを施行した43病变を対象とした。街前、術

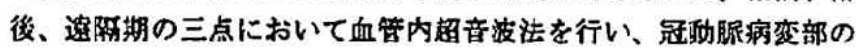
全血管断面稍、血管内眰断面稍、アテローム断面稍を叶制した。さ

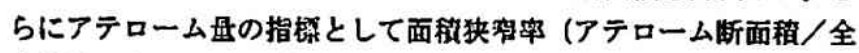
血管断面䖽 $\times 100$ ）を算出した。正のリモデリング群（遂焐期全血管

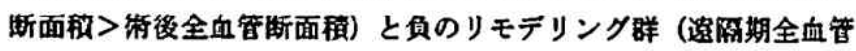

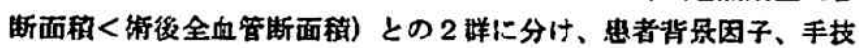

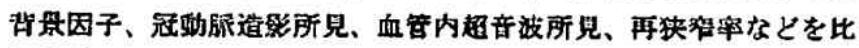
敀检刢した。

DCA施行後43例中 21 例 (49\%) が蚞界期にかけて正のリモテリン グを生じ、22例 (51\%) が负のリモデリングを生じた。监变量解析 において正のリモデリングを生じた群は術肺の全血管断面椯、およ

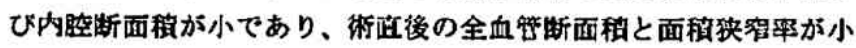

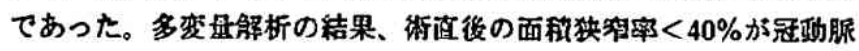
の正のリモテリングを予测する唯一の䖵立した因子であった（オッ ス比6.7、 $\mathrm{p}=0.004)$ 。正のリモデリングを生した群では負のリモテリ ンクを生じた群に比して再㹟窝率が低い偩向がみられた (18.2\% vs. $9.5 \%, p=0.4)$ 。

本研究においてDCA施行後の残存アテローム舟が衡後の冠聃服リ モデリングに影帮をおよぼすことが明らかとなった。DCA施行後の

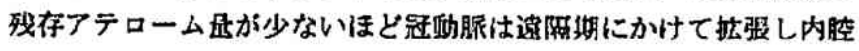
が保持され、再㹟视過程を㧕制する可能性が然えられた。

DCA施行後の残存アテロームfitは冠㕫腿リモデリングを規定し

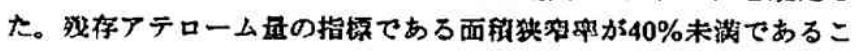
とが、邀隔期の正の冠贸脈りモテリングを予测する唯一の独立した 因子であった。

\section{蝓文舞查の要旨}

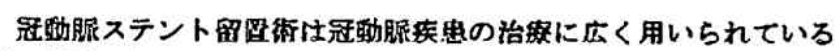
が、異物であるステントに対する血管内皮の反忘が墖剩な剒合は、

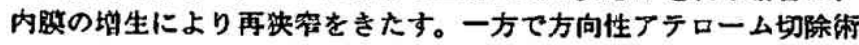
(Directional Coronary Atherectomy: DCA) は冠洏腿内アテロームを直 摸切除し除去することが可能な唯一の治嚓法である。DCA後の再决

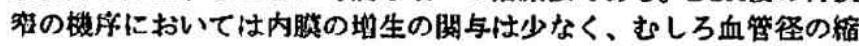
小（鱼のリモデリング）が主因と考えられている。本研究では血管 内超音波法を用いて DCA施行後の冠种脈リモデリングに関与する因 子を明らかにすることを目的とした。その結果、DCA施行直後の残

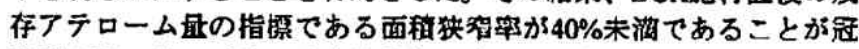
叻腿の正のリモデリングを予测する唯一の独立した因子であった。

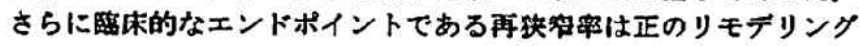

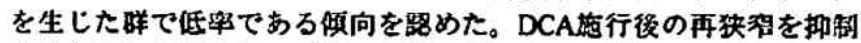

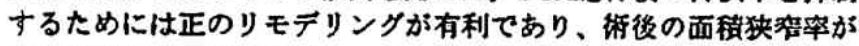
40\%末湖となるまでアテロームの切除を行うべであると示咹され た。

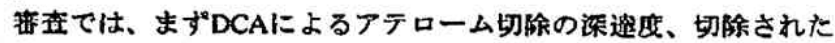

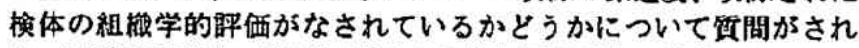

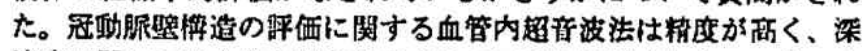
这度に閣しては十分な解価がなされていると回答された。一方、本 研究ではアテロームの組維学的、生化学的挨时はなされておらず、 この点が本研究の限界であると回答された。また今後の血管内超音

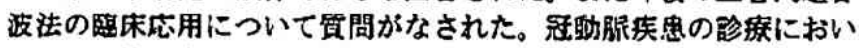
ては、心经梗塞の発生母地となる可能性のある不安定なアテローム

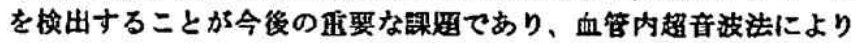

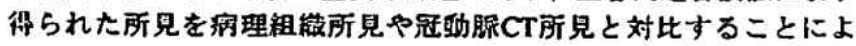

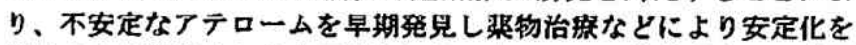
图ることが期待されると回答された。炊にDCAの使用頻度、冠動㟲 ステントとの使い分けに閣して質問がなされた。聚剂楁出性ステン トの登期によりDCAの使用频度は珬少したが、現在でも約 $5 \%$ 症 例に用いられており、とくに分岐部痛帘においてステントを留睓す る前にアテロームを減少させるための処偍として有用性が䟯いと回 答された。报後にDCA施行後 6 々月以降の、さらに长期的な血管り モテリングの状應や予後について検时がなされていろかどうかにつ き筫間がなされた。それに対して冠的脈造影、血管内超音波法は侵

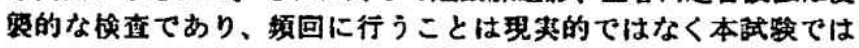
6 ケ月以降の追跡がなされていないと回答された。この点に関して 低侵毁な冠洏服CT挨李を用いて追跡することが可能ではないかと助 当を受けた。

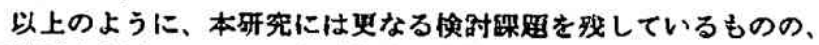
军秒腿方向性フテローム切除衡後の血管リモデリングの原因として 攻存アテローム岳の閣与を明らかにした有总䉝な監床研究であると 毇価された。

踰文教查担当者 主查 内科学 小川 聡 外科学 四津 良平 再生医举 绍田 患一 病理学 周田 保典

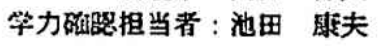
察等委目長 : 四津 良平 